\title{
Carcass and Meat Characteristics of Male Bali Cattle in Indonesian Smallholder Farms Fed Ration with Different Protein Levels
}

\author{
P. K. Tahuk ${ }^{\mathrm{a}, *}$, S. P. S Budhi ${ }^{\mathrm{b}}$, Panjono ${ }^{\mathrm{b}}$, \& E. Baliarti ${ }^{\mathrm{b}}$ \\ aDepartment of Animal Science, Faculty of Agriculture, Timor University, \\ Kefamenanu, East Nusa Tenggara 85613, Indonesia \\ 'Faculty of Animal Science, Gadjah Mada University, \\ Jalan Fauna No. 3 Bulaksumur, Yogyakarta 55281, Indonesia \\ *Email of corresponding author: paulklau@yahoo.co.id \\ (Received 22-05-2018; Reviewed 24-07-2018; Accepted 01-10-2018)
}

\begin{abstract}
The objective of research was to determine the effect of different protein levels on the carcass and meat characteristics of male Bali cattle fattened in smallholder farms. The cattle used were 18 heads aged 2 to 2.5 years with initial body weight of $229.86 \pm 12.46 \mathrm{~kg}$. The experimental cattle were randomly divided into 3 treatment groups i.e., $T_{0}, T_{1}$, and $T_{2}$. The $T_{0}$ group cattle were fed ration according to traditional practices of fattening cattle by farmers $\left(100 \%\right.$ forage). The $T_{1}$ group cattle were fed ration with $12 \% \mathrm{CP}$ and $72 \%$ TDN. The $\mathrm{T}_{2}$ group cattle were fed ration with $15 \% \mathrm{CP}$ and $72 \%$ TDN. The variables measured were final body weight and the characteristics of the carcass (meat, fat, and ratio of meat to bone), and meat quality including the chemical composition of the meat (protein, fat, and collagen), meat tenderness, cooking loss, water holding capacity, and degree of acidity (pH). Data were analyzed by variance analysis. Results of research showed that the final body weight, and weight of carcass, meat, and fat of $T_{1}$ and $T_{2}$ groups were similar; conversely, those parameters in $T_{0}$ group cattle were lower $(P<0.05)$ that those in $T_{1}$ and $T_{2}$ groups cattle. The meat protein content of $T_{1}$ and $T_{0}$ groups cattle were similar; conversely, $T_{2}$ group cattle had lower $(P<0.05)$ meat protein content compared to $T_{1}$ and $T_{0}$ groups cattle. Fat content of $T_{1}$ group of cattle was higher $(P<0.05)$ than that of $\mathrm{T}_{0}$ group; while moisture contents and cooking losses of $T_{0}$ group cattle were higher $(P<0.05)$ compared to those of $T_{1}$ and $T_{2}$ groups cattle. Collagen content of meat in $T_{1}$ group cattle was higher than $(P<0.05)$ that in $T_{0}$ group cattle, but $T_{2}$ group cattle had similar meat collagen content to $T_{1}$ and $T_{0}$ groups cattle. Meat tenderness of $T_{1}$ group cattle was higher $(P<0.05)$ compared to those of $T_{0}$ and $\mathrm{T}_{2}$ group cattle. It is concluded that the male Bali cattle fed ration with $12 \% \mathrm{CP}$ and $72 \%$ TDN can increase the carcass characteristics and meat quality. This proves that the productivity of male Bali cattle can be increased when fed ration with adequate protein with a balanced energy content.
\end{abstract}

Keywords: protein level, Bali cattle fattening, smallholder farms, carcass characteristics, meat quality

\section{INTRODUCTION}

Bali cattle are indigenous beef cattle in Indonesia which have great potential for producing quality meat under local conditions compared to the other domestic strains of cattle or imported cattle. Carcass production is quite high (Oka et al., 2012), with an average reaching $52.76 \%$ (Suryanto et al., 2014). Moreover, Bali cattle have adapted to poor nutritional conditions such as those found during the dry season, are highly fertile, and have low calf mortality (Panjaitan et al., 2014). The potential value of Bali cattle has encouraged farmers to raise them to increase their family income levels.

Nevertheless, the pattern for raising livestock on a typical smallholder farm is still largely traditional in terms of feeding, which means the quality assurance and quantity impact on livestock productivity are not optimized (Tahuk \& Dethan, 2010). Evidence of this situation was documented by Panjaitan et al. (2014) who reported that average daily weight gain of male Bali cattle fattened with Leucaena leucocephala was $0.512 \mathrm{~kg} /$ day during January-June but the average only $0.35 \mathrm{~kg} /$ day during July-December. Tahuk \& Dethan (2010) reported that the average daily weight gain (ADG) and feed conversion ratio for male Bali cattle fattened by farmers during the rainy season were $0.53 \mathrm{~kg} /$ day and 7.55, respectively. The report by Tahuk et al. $\left(2018^{\mathrm{b}}\right)$ indicated the ADG of male Bali Cattle fattened in smallholder farms during the rainy season was $0.51 \mathrm{~kg} / \mathrm{head} /$ day; conversely, during the dry season, the ADG was only $0.30 \mathrm{~kg} / \mathrm{head} /$ day.

The above reports show that Bali cattle definitely have enough potential to produce profitable carcasses when the animals are able to obtain sufficient feed. 
Conversely, the carcasses produced by these livestock were not optimal when the feed obtained was not sufficient in quality or quantity.

Observations made by groups of farmers also show that the availability of protein is abundant, more than enough to meet the needs of livestock. This condition of sufficiency is established because the majority of farmers can use legumes as animal feed. However, the availability of digestible energy is not sufficient because the farmers rely on the structural carbohydrate sources such as grassy fields (Tahuk et al., 2017). As a result, cattle are not able to obtain a proper balance between protein and energy sufficiency. Therefore, the low performance of Bali cattle when fed with this forage in feedlots is presumably related to the lack of availability of digestible energy in the forage used. According to Ali et al. (2014), the indicator for feed efficiency is average daily gain (ADG). Reduced or low body weight gain may be due to the lack of feed efficiency in feed ingredients. Therefore, the amount of increase in body weight is also an indicator of the quality of feed used in fattening livestock (Tahuk \& Dethan, 2010).

Tahuk et al. (2017) reported that improving the fattening feed by adding digestible carbohydrates with a formulation consisted of $12 \%$ crude protein (CP) and $72 \%$ total digestible nutrients (TDN), which resulted in a higher growth rate for male Bali cattle fattened on smallholder farms. Efforts are being made to improve the performance of male Bali cattle being fattened on smallholder farms by improving the composition of the feed, considering both sufficient quantities and proper nutrient balance, especially the balance between protein and energy. Referring to the report by Tahuk et al. (2017) above, the use of CP and TDN at the level of $12 \%$ and $75 \%$ is thought to be able to produce better carcass characteristics and meat quality compared with other types of feed treatments. Based on the background information cited above, this study was focused on determining carcass production and meat quality of male Bali cattle on smallholder farms when fattened with rations with different protein levels.

\section{MATERIALS AND METHODS}

\section{Cattle, Research Design, and Animal Feed}

The research was conducted for a 90 day period, using 18 male Bali Cattle aged 2 to 2.5 years with average initial body weight of $229.86 \pm 12.46 \mathrm{~kg}$. Each animal was placed randomly within individual cages, which created 18 individual $1.5 \times 2.0 \mathrm{~m}$ plots that were equipped with separate feed and water boxes. The 90 days period for cattle raising included 14 days for adjustment period. Feed was distributed three times a day, at 7:00 a.m., 12:00 a.m., and 17:00 p.m. local time. Drinking water was available ad libitum.

Forage and concentrates were fed to the cattle separately; in the first stage of feeding, the cattle were given forage; after $60 \mathrm{~min}$ allotted for forage consumption, in the second stage the cattle were given supplemental concentrates as needed. To analyze the chemical composition and quality of meat, samples (as much as 700 $\mathrm{g}$ each) were taken from the Longissimus dorsi and Biceps femoris muscles.

The research design used was completely randomized design. The cattle were divided into three treatment groups, with one group designated as a control group $\left(\mathbf{T}_{0}\right)$, and two groups selected to be treated with specific, modified rations $\left(T_{1}\right.$ and $\left.T_{2}\right)$. Each group consisted of six cattle. In the $T_{0}$ group cattle, the ration fed to the cattle varied according to the traditional practice used by farmers for fattening cattle. The crude protein (CP) and total digestible nutrients (TDN) contents of food consumed by the $\mathrm{T}_{0}$ group were determined to be $17.0 \%$ and $65.51 \%$, respectively. For the $T_{1}$ group and $T_{2}$ group cattle, rations were prepared with different levels of crude protein, containing iso-energy in the form of TDN. The $\mathbf{T}_{1}$ group cattle were fed rations with $12 \%$ crude protein $(\mathrm{CP})$ and $72 \%$ energy $(\mathrm{TDN})$, and the $\mathbf{T}_{2}$ group cattle were fed rations with $15 \% \mathrm{CP}$ and $72 \%$ energy (TDN). The rations were composed of native grass, Gliricidia sepium, corn meal, and rice bran. The type and chemical composition of feedstuffs and the ration formulations are shown in Tables 1 and 2. In order to avoid a shortage of nutrients, especially minerals, during the fattening process, the experimental cattle were given additional mineral supplements produced by Medion, Bandung composed of 165,000 mg Calcium; 52,000 mg Phosphorous; 157,000 mg Sodium; 2500 mg Iron; 2500 mg Copper; 2000 mg Manganese; 125 mg Iodine; 50 mg Cobalt; $5000 \mathrm{mg}$ Selenium; and $10 \mathrm{mg}$ Zinc. The distribution was $2 \%$ per $100 \mathrm{~kg}$ of concentrate mixture used.

\section{Measurement Variables and Data Collection}

The variables measured in this study were the characteristics of the carcass (meat, fat, and ratio of meat to bone), and meat quality including the chemical composition of the meat (protein, fat, and collagen), meat tenderness, cooking loss, water holding capacity, and degree of acidity $(\mathrm{pH})$.

Determination of slaughter weight and carcass characteristics. The experimental cattle were slaughtered after the animals had previously fasted for \pm 24 hours. The slaughter weights were obtained by weighing the cattle shortly before slaughtering. The hot carcass weight was obtained by weighing the carcass after slaughtering. The hot carcass percentage was obtained by comparing the hot carcass weight to the slaughter weight, multiplied by $100 \%$. The percentages of carcass components of meat, trim fat, and bone were obtained by comparing the weight of each component of the carcasses with the carcass weight, multiplied by $100 \%$.

Determination of the chemical composition of the meat. The chemical compositions of meats were determined by using the Near-Infrared (NIR) Spectroscopy method by utilizing the Food Scan Meat Analyzer (Osborne, 2006). Procedure for determination: The samples were ground (milled) using a meat grinder; then the samples were weighed $( \pm 30 \mathrm{~g})$; then the samples were inserted into the cup/sample cups (with $15 \mathrm{~cm}$ diameter) and then leveled to the average (surface sealed). 
Table 1. The chemical composition of feedstuffs used for male Bali cattle fattening on smallholder farms, with different levels of protein $(\%$ of DM)

\begin{tabular}{lcccccccccc}
\hline \multicolumn{1}{c}{ Kinds of feed } & DM $(\%)$ & OM & Ash & CP & EE & CF & NFE $^{*}$ & TDN** & NDF & ADF \\
\hline Native grass & 36.54 & 84.71 & 15.29 & 6.08 & 4.11 & 32.8 & 41.72 & 57.3 & 68.72 & 39.74 \\
Gliricidia sepium & 24.27 & 87.56 & 12.44 & 24.19 & 12.55 & 14.51 & 36.31 & 72.21 & 32.98 & 21.87 \\
Leucaena leucocephala & 25.25 & 90.19 & 9.81 & 25.65 & 8.41 & 18.96 & 29.52 & 79.79 & 34.11 & 18.47 \\
Sesbania grandiflora & 20.33 & 85.29 & 14.71 & 21.77 & 8.9 & 13.18 & 32.94 & 75.06 & 24.72 & 15.85 \\
Pennisetum purpuroides & 25.24 & 86.62 & 13.38 & 11.98 & 4.68 & 31.07 & 32.37 & 46.69 & 68.09 & 36.24 \\
Banana stem (Musa x paradisiaca) & 10.40 & 85.49 & 14.51 & 3.31 & 7.57 & 32.36 & 32.08 & 54.77 & 47.65 & 25.85 \\
Banana leaves (Musa x paradisiaca) & 22.12 & 91.06 & 15.01 & 4.37 & 23.17 & 8.9 & 39.87 & 50.69 & - & - \\
Cassava leaves (Manihot utilissima) & 24.42 & 90.34 & 9.66 & 24.52 & 8.23 & 19.47 & 31.16 & 79.45 & - & - \\
Corn meal & 90.09 & 98.81 & 1.19 & 7.89 & 1.44 & 1.82 & 87.66 & 87.66 & 22.14 & 1.99 \\
Rice bran & 90.42 & 84.49 & 8.26 & 6.97 & 2.03 & 17.37 & 65.37 & 65.37 & 54.67 & 40.32 \\
\hline
\end{tabular}

Note: ${ }^{*} \mathrm{NFE}=[100-(\% \mathrm{Ash}+\% \mathrm{CF}+\% \mathrm{EE}+\% \mathrm{CP})] ;{ }^{* *} \mathrm{TDN}=$ According to the equation from Hartadi et al. $(1980) ; \mathrm{NDF}=\mathrm{Neutral}$ detergent fiber, ADF= Acid detergent fiber

Table 2. The rations used for male Bali cattle fattening on smallholder farms, with different levels of protein

\begin{tabular}{clccc}
\hline \multirow{2}{*}{ Treatments } & \multicolumn{1}{c}{ Feedstuff } & $\begin{array}{c}\text { Number } \\
\text { of usage } \\
\end{array}$ & & \multicolumn{2}{c}{$\begin{array}{c}\text { Ration nutrient } \\
\text { composition }(\%)\end{array}$} \\
\cline { 4 - 5 } & & 100 & 17.09 & 65.51 \\
$\mathrm{~T}_{0}^{*}$ & Forage & 14 & 0.85 & 9.92 \\
$\mathrm{~T}_{1}$ & Native grass & 30 & 7.26 & 21.66 \\
& Gliricidia sepium & 39 & 3.08 & 32.66 \\
& Corn meal & 17 & 1.18 & 8.61 \\
& Rice bran & 100 & 12.37 & 72.85 \\
& Total & 13 & 0.79 & 9.21 \\
$\mathrm{~T}_{2}$ & Native grass & 46 & 11.13 & 33.22 \\
& Gliricidia sepium & 28 & 2.21 & 23.45 \\
& Corn meal & 13 & 0.91 & 6.58 \\
& Rice bran & 100 & 15.03 & 72.46 \\
\hline
\end{tabular}

Note: *Adjusted with feed provided by the farmers. Forage proportions included: natural grass $33.76 \%$, Gliricidia sepium $26.71 \%$, Leucaena leucocephala $26.99 \%$, Sesbania glandiflora $3.52 \%$, Pennisetum purpuroidess $1.78 \%$, and other feedstuffs $7.24 \%$.

The computer that was connected with the food-scan tool was turned on; the icon for food scan was clicked or "Menu" was selected and then the food-scan program was launched; configuration was selected by specifying the parameters of the test including fat, protein, collagen, and water; wavelengths were set between 800-1400 $\mathrm{nm}$. The sample cup was inserted into the food-scan space; the food-scan analysis tool was selected and activated by pressing "Run/On." 15 minutes elapses, during which time the tool detected and read the average moisture, protein, fat, and collagen in \% units. At the end, the sample was given a unique sample code and the file reading was saved.

\section{Determination of meat quality}

1. Determination of Water Holding Capacity (WHC) (Abraham \& Sivakumar, 2000). The stages of measurement begin with determining free water content (FWC). Measurement procedures: Around $\pm 0.3 \mathrm{~g}$ sample was placed on filter paper. The two plates were pressed under a load of $35 \mathrm{~kg}$ for \pm 5 minutes. The image area was established with a plastic transparency and the specific area $\left(\mathrm{cm}^{2}\right)$ was determined. The equation to calculate WHC was: $\mathrm{mgH}_{2} 0=$ volume of the wet area $\left(\mathrm{cm}^{2}\right) / 0.0948$. Free water content (FWC) (\%) was calculated using the following equation: $\mathrm{mgH}_{2} \mathrm{O} /$ sample weight $(\mathrm{mg}) \times 100 \%$. The total water content (TWC) was determined by using the following procedure: the filter paper (initial weight) was weighed, and around $\pm 1 \mathrm{~g}$ of sample was weighed (sample weight) and wrapped with the filter paper. The oven was preheated and the sample was heated at $110^{\circ} \mathrm{C}$ for 8 hours. The sample was weighed after being removed from the oven (final weight). The TWC (\%) was calculated using the following equation: sample weight - (final weight - initial weight) / sample weight $(\mathrm{mg}) \times 100 \%$. The WHC (\%) was calculated using the following equation: TWC (\%) - FWC (\%).

2. Determination of meat tenderness $\left(\mathrm{kg} / \mathrm{cm}^{2}\right)$ (Shear force Warner-Bratzler method (Abraham \& Sivakumar, 2000); AMSA, 2015). Measurement procedure: Around $20 \mathrm{~g}$ sample was weighed and placed in a polypropylene plastic and packed with a vacuum pack. The sample was heated in a water bath at $80^{\circ} \mathrm{C}$ for 30 minutes. Next, the sample was removed from the water bath and after cooling, the sample field of the size of $1.5 \times 0,67 \mathrm{~cm}$ or $1 \times 1 \mathrm{~cm}$ was determined or form a tube measuring a certain area in the direction of the fibers of the meat. The test sample plate was placed on the tool with the fiber direction in a transverse position, and the Warner-Braztler shear machine was turned on. The tool cut the meat fibers. The result of measurement was recorded. The measurement was repeated 2 or 3 times.

3. Determination of the degree of acidity $(\mathrm{pH})$ (Abraham \& Sivakumar, 2000). Measurement procedure: Samples of meat were mashed by chopping or with a meat grinder. Around 2 grams of the mashed/ground meat was weighed for a sample and then the sample was diluted in $18 \mathrm{~mL}$ of distilled water, stirred/mixed until homogeneous, and 
then the mixture was filtered. The following steps were done using a $\mathrm{pH}$ meter calibrated by using buffer solutions of $\mathrm{pH} 4$ and $\mathrm{pH}$ 7. The $\mathrm{pH}$ of the filtrate samples were measured by a $\mathrm{pH}$ meter and the measurements were recorded. Each sample was measured in duplicated; after each $\mathrm{pH}$ measurement, the $\mathrm{pH}$ meter was checked for standardized calibration with buffer solutions of $\mathrm{pH} 7$ and $\mathrm{pH} 4$. The specification tool used was Testers: HI 9811X Piccolo, Hanna instrument.

4. Determination of cooking loss (Jama et al., 2008). Measurement procedure: Around $\pm 20 \mathrm{~g}$ sample was weighed and placed in a plastic polypropylene. The samples were packed using a vacuum pack then heated in a water bath at $80^{\circ} \mathrm{C}$ for 30 minutes. The cooking loss (\%) was determined by equation: A - B / A x 100\%, where A and B were the weights of the sample before and after heating $(\mathrm{g})$.

\section{Statistical Analysis}

Data were analyzed by one way analysis of variance. If there were differences among the treatments, further tests were conducted by Duncan's Multiple Range Test (DMRT) (Steel \& Torrie, 1995). SPSS software version 19 was used to facilitate the analysis.

\section{RESULTS}

\section{Characteristics of the Carcass}

The slaughter weight, carcass properties, meat and fat weights $(\mathrm{kg})$ of the male Bali cattle in the $T_{1}$ and $T_{2}$ groups were relatively similar and higher $(\mathrm{P}<0.05)$ compared those in $\mathrm{T}_{0}$ group. The percentage of carcasses, meat-to-bone ratio, weight and bone percentage of the three groups showed no significant differences. Nonetheless, male Bali cattle fed with ration with $12 \%$ $\mathrm{CP}$ ( $\mathrm{T}_{1}$ group) had a better carcass percentage and the meat-to-bone ratio tended to be higher than the other two groups $\left(\mathrm{T}_{0}\right.$ and $\left.\mathrm{T}_{2}\right)$. The meat percentage of male Bali cattle fed with $100 \%$ forage according to the farmer tradition $\left(\mathrm{T}_{0}\right)$ was higher $(\mathrm{P}<0.05)$ than those of cattle fed with ration with $15 \% \mathrm{CP}$ and $72 \% \mathrm{TDN}$ ( $\mathrm{T}_{2}$ group). However, the Bali cattle fed with ration with $12 \% \mathrm{CP}$ and $72 \%$ TDN $\left(\mathrm{T}_{1}\right)$ had similar meat percentages with those fed with 100\% forage according to the farmer tradition (T0) and those fed with 15\% CP and 72\% TDN ( $\mathrm{T}_{2}$ group). The meat percentages of male Bali cattle fed $100 \%$ forage ( $T_{0}$ group) and those fed ration with $12 \%$ $\mathrm{CP}$ and $72 \%$ TDN ( $\mathrm{T}_{1}$ group) were high in relation to a lower proportion of fat $(\mathrm{kg})$ when compared with the male Bali cattle fed ration with $15 \% \mathrm{CP}$ and $72 \%$ TDN ( $\mathrm{T}_{2}$ group) (Table 3$)$.

\section{Meat Quality}

Meat moisture, protein, collagen, and fat. The moisture/water content (\%) of the meat of Bali cattle fed 100\% forage according to the farmer tradition ( $\mathrm{T}_{0}$ group) was higher $(\mathrm{P}<0.05)$ than those of Bali cattle fed ration with $12 \% \mathrm{CP}$ and $72 \% \mathrm{TDN}$ ( $\mathrm{T}_{1}$ group) and $15 \% \mathrm{CP}$ and $72 \%$
TDN ( $\mathrm{T}_{2}$ group). However, meat protein content (\%) of male Bali cattle fed with ration with $15 \% \mathrm{CP}$ and $72 \%$ TDN ( $\mathrm{T}_{2}$ group) was higher $(\mathrm{P}<0.05)$ than those fed with $15 \% \mathrm{CP}$ and $72 \% \mathrm{TDN}$ ( $\mathrm{T}_{1}$ group), and the meat protein content of the male Bali cattle fed with $100 \%$ forage according to the farmer tradition ( $\mathrm{T}_{0}$ group) was relatively equal to those of male Bali cattle fed with ration with $12 \%$ $\mathrm{CP}\left(\mathrm{T}_{1}\right.$ group) and $15 \% \mathrm{CP}\left(\mathrm{T}_{2}\right.$ group). The fat content $(\%)$ of meat in the male Bali cattle fed with ration with $12 \%$ $\mathrm{CP}$ and $72 \%$ TDN ( $\mathrm{T}_{1}$ group) was higher $(\mathrm{P}<0.05)$ than those of fed $100 \%$ forage according to the farmer tradition ( $\mathrm{T}_{0}$ group); however, the meat fat content of male Bali cattle fed with ration with 15\% CP and 72\% TDN ( $\mathrm{T}_{2}$ group) was relatively equal to male Bali cattle fed with $100 \%$ forage according to the farmer tradition $\left(\mathrm{T}_{0^{\prime}}\right)$ and male Bali cattle fed with ration with $12 \% \mathrm{CP}$ and $72 \%$ TDN ( $\mathrm{T}_{1}$ group). The collagen content $(\%)$ of meat in the male Bali cattle fed ration with $12 \% \mathrm{CP}$ and $72 \%$ TDN $\left(\mathrm{T}_{1}\right.$ group) was higher $(\mathrm{P}<0.05)$ than those of male Bali cattle fed $100 \%$ forage according to the farmer tradition ( $\mathrm{T}_{0}$ Group). In contrast, the collagen content of meat of male Bali cattle fed ration with 15\% CP and 72\% TDN ( $\mathrm{T}_{2}$ group) was relatively similar to those fed with $100 \%$ forage ( $\mathrm{T}_{0}$ group) and $12 \% \mathrm{CP}$ and $72 \% \mathrm{TDN}$ ( $\mathrm{T}_{1}$ group).

Meat tenderness, cooking loss, water holding capacity, and degree of acidity. The meat tenderness $\left(\mathrm{kg} / \mathrm{cm}^{2}\right)$ of the male Bali cattle fed with 100\% forage according to the farmer tradition ( $\mathrm{T}_{0}$ group) and those fed with ration with $15 \% \mathrm{CP}$ and $72 \%$ TDN ( $\mathrm{T}_{2}$ group) were relatively close or similar, but the meat tenderness of both groups were lower $(\mathrm{P}<0.05)$ compared to those of male Bali cattle fed with ration with $12 \% \mathrm{CP}$ and $72 \%$ TDN ( $\mathrm{T}_{1}$ group). The tenderness of meat in the male Bali cattle fed with

Table 3. Carcass characteristics of male Bali cattle fattened on smallholder farms with different levels of protein

\begin{tabular}{lccc}
\hline \multicolumn{1}{c}{ Variables } & $\mathrm{T}_{0}$ & $\mathrm{~T}_{1}$ & $\mathrm{~T}_{2}$ \\
\hline DM intake $(\mathrm{BW} \%)^{*}$ & $1.76 \pm 0.19^{\mathrm{a}}$ & $2.71 \pm 0.12^{\mathrm{c}}$ & $2.40 \pm 0.14^{\mathrm{b}}$ \\
$\begin{array}{l}\text { Feed consumption } \\
(\mathrm{kg})^{*}\end{array}$ & $4.60 \pm 0.60^{\mathrm{a}}$ & $7.76 \pm 0.28^{\mathrm{c}}$ & $6.60 \pm 0.24^{\mathrm{b}}$ \\
Initial body weight & $233.33 \pm 13.80$ & $222.75 \pm 9.74$ & $233.50 \pm 12.31$ \\
$(\mathrm{~kg})^{*}$ & & & \\
Final body weight $(\mathrm{kg})^{*}$ & $260.67 \pm 15.31$ & $286.08 \pm 9.11$ & $275.92 \pm 25.33$ \\
Slaughter weight $(\mathrm{kg})$ & $228.60 \pm 8.65^{\mathrm{a}}$ & $249.40 \pm 4.16^{\mathrm{b}}$ & $251.20 \pm 13.94^{\mathrm{b}}$ \\
Carcass weight $(\mathrm{kg})$ & $123.64 \pm 7.89^{\mathrm{a}}$ & $138.68 \pm 1.77^{\mathrm{b}}$ & $137.60 \pm 7.17^{\mathrm{b}}$ \\
Carcass percentage & $54.07 \pm 2.39$ & $55.61 \pm 0.93$ & $54.79 \pm 0.98$ \\
Meat weight $(\mathrm{kg})$ & $84.98 \pm 4.47^{\mathrm{a}}$ & $93.16 \pm 1.94^{\mathrm{b}}$ & $89.60 \pm 2.17^{\mathrm{b}}$ \\
Meat percentage & $68.78 \pm 1.40^{\mathrm{b}}$ & $67.18 \pm 1.19^{\mathrm{ab}}$ & $65.19 \pm 1.88^{\mathrm{a}}$ \\
Bone weight $(\mathrm{kg})^{\mathrm{ns}}$ & $29.82 \pm 3.23$ & $32.20 \pm 1.92$ & $33.56 \pm 3.49$ \\
Bone percentage & $24.07 \pm 1.28$ & $23.21 \pm 1.12$ & $24.34 \pm 1.28$ \\
Fat weight $(\mathrm{kg})^{\mathrm{ns}}$ & $8.73 \pm 0.67^{\mathrm{a}}$ & $13.60 \pm 1.82^{\mathrm{b}}$ & $14.52 \pm 1.65^{\mathrm{b}}$ \\
Fat percentage & $7.06 \pm 0.23^{\mathrm{a}}$ & $9.82 \pm 1.40^{\mathrm{b}}$ & $10.53 \pm 0.74^{\mathrm{b}}$ \\
Meat to bone rations & $2.87 \pm 0.21$ & $2.90 \pm 0.14$ & $2.69 \pm 0.22$ \\
Non-carcass weight & $104.96 \pm 5.71^{\mathrm{a}}$ & $110.72 \pm 3.82^{\mathrm{ab}}$ & $113.60 \pm 7.48^{\mathrm{b}}$ \\
(kg) & & &
\end{tabular}

Note: Data were presented in average $\pm \mathrm{SD}$; ${ }^{\text {ab }}$ mean in the same row with different supersripts differ significantly $(\mathrm{P}<0.05)$; ns= not significant; ${ }^{*}$ According to Tahuk et al. (2017); $\mathrm{T}_{0}=$ group cattle fed $100 \%$ forage; $\mathrm{T}_{1}=$ group cattle fed ration with $12 \% \mathrm{CP}$ and $72 \% \mathrm{TDN} ; \mathrm{T}_{2}=$ group cattle fed ration with $15 \% \mathrm{CP}$ and $72 \%$ TDN. 
ration with $12 \% \mathrm{CP}$ and $72 \% \mathrm{TDN}$ ( $\mathrm{T}_{1}$ group) was related to the high water-holding capacity and low cooking loss compared with the other two groups.

The meat cooking loss (\%) in the male Bali cattle fed with $100 \%$ forage according to the farmer tradition $\left(\mathrm{T}_{0}\right.$ group) was higher $(\mathrm{P}<0.05)$ than those fed with ration with $12 \% \mathrm{CP}$ and $72 \% \mathrm{TDN}$ ( $\mathrm{T}_{1}$ group) and $15 \% \mathrm{CP}$ and $72 \%$ TDN ( $\mathrm{T}_{2}$ group). However, male Bali cattle fed with ration with $12 \% \mathrm{CP}$ and $72 \% \mathrm{TDN}$ ( $\mathrm{T}_{1}$ group) and $15 \%$ $\mathrm{CP}$ and $72 \%$ TDN ( $\mathrm{T}_{2}$ group) exhibited the relatively similar cooking loss. The values of the water-holding capacity (\%) in the meat of male Bali cattle fed $100 \%$ forage according to the farmer tradition ( $\mathrm{T}_{0}$ group), fed ration with $12 \% \mathrm{CP}$ and $72 \% \mathrm{TDN}$ ( $\mathrm{T}_{1}$ group), and fed ration with $15 \% \mathrm{CP}$ and $72 \% \mathrm{TDN}$ ( $\mathrm{T}_{2}$ group) exhibited non-significant differences and were within the normal range. The degree of acidity $(\mathrm{pH})$ of meat from the male Bali cattle fed $100 \%$ forage according to the farmer tradition ( $\mathrm{T}_{0}$ group), fed ration with $12 \% \mathrm{CP}$ and $72 \% \mathrm{TDN}$ ( $\mathrm{T}_{1}$ group), and fed ration with $15 \% \mathrm{CP}$ and $72 \% \mathrm{TDN}$ ( $\mathrm{T}_{2}$ group) showed non-significant differences (Table 4 ).

\section{DISCUSSION}

\section{Carcass Characteristics}

The results of this study showed that feeding male Bali cattle with rations containing $12 \% \mathrm{CP}$ and $72 \% \mathrm{TDN}$ or $15 \% \mathrm{CP}$ and $72 \%$ TDN could increase the slaughter and carcass weight and components of the carcass (meat and fat), when compared to the control group cattle fed $100 \%$ forage according to the farmer tradition. This difference is related to the inadequate intakes of protein and energy in the cattle fed 100\% forage according to the farmer tradition ( $\mathrm{T}_{0}$ group). According to Tahuk et al. $\left(2018^{\mathrm{a}}\right)$, feeding male Bali cattle during fattening period with rations containing $12 \% \mathrm{CP}$ and $72 \%$ TDN improved the nitrogen balance and blood metabolites. This condition had a direct impact on the animal growth as was reflected in the improved growth

Table 4. The meat quality of meat from male Bali cattle fattened on smallholder farms with different levels of protein

\begin{tabular}{lccc}
\hline \multicolumn{1}{c}{ Variables } & \multicolumn{1}{c}{$\mathrm{T}_{0}$} & \multicolumn{1}{c}{$\mathrm{T}_{1}$} & $\mathrm{~T}_{2}$ \\
\hline $\begin{array}{l}\text { Water/moisture } \\
(\%)\end{array}$ & $72.75 \pm 0.54^{\mathrm{b}}$ & $71.97 \pm 0.54^{\mathrm{a}}$ & $71.73 \pm 0.52^{\mathrm{a}}$ \\
Protein (\%) & $21.62 \pm 0.27^{\mathrm{ba}}$ & $21.21 \pm 0.47^{\mathrm{a}}$ & $21.71 \pm 0.14^{\mathrm{b}}$ \\
Fat (\%) & $3.03 \pm 0.76^{\mathrm{a}}$ & $4.68 \pm 1.51^{\mathrm{b}}$ & $3.62 \pm 0.63^{\mathrm{ab}}$ \\
Collagen (\%) & $1.56 \pm 0.14^{\mathrm{a}}$ & $1.72 \pm 0.09^{\mathrm{b}}$ & $1.66 \pm 0.08^{\mathrm{ab}}$ \\
Cooking loss (\%) & $40.50 \pm 1.11^{\mathrm{b}}$ & $37.36 \pm 2.31^{\mathrm{a}}$ & $37.60 \pm 0.88^{\mathrm{a}}$ \\
$\begin{array}{l}\text { Water holding } \\
\text { capacity (\%) }\end{array}$ & $14.93 \pm 1.60$ & $15.79 \pm 2.48$ & $15.07 \pm 1.40$ \\
$\begin{array}{l}\text { Tenderness } \\
\left(\mathrm{kg} / \mathrm{cm}^{2}\right)\end{array}$ & $7.94 \pm 1.46^{\mathrm{b}}$ & $5.58 \pm 0.79^{\mathrm{a}}$ & $8.80 \pm 0.86^{\mathrm{b}}$ \\
$\mathrm{pH} \mathrm{H}^{\text {ns }}$ & & & \\
\hline
\end{tabular}

Note: Data were presented in average $\pm S D$; ${ }^{\text {ab }}$ mean in the same row with different supersripts differ significantly $(\mathrm{P}<0.05)$; $\mathrm{ns}=$ not significant; $\mathrm{T}_{0}=$ group cattle fed $100 \%$ forage; $\mathrm{T}_{1}=$ group cattle fed ration with $12 \% \mathrm{CP}$ and $72 \% \mathrm{TDN} ; \mathrm{T}_{2}=$ group cattle fed ration with $15 \%$ $\mathrm{CP}$ and $72 \%$ TDN. performance and synthesis of the body tissues (Tahuk et al., 2017).

The carcass characteristics and chemical composition of the meat of male Bali cattle were significantly influenced by the dietary energy and protein levels ( $\mathrm{Li}$ et al., 2014). The optimum ration quality in cattle was ration containing $13 \%$ crude protein, resulting in the highest carcass yields. Increasing CP concentrations up to $14.5 \%$ does not further improve the carcass performance. Similarly, cattle fed rations with only $11.5 \% \mathrm{CP}$ yield lower carcass production (Gleghorn et al., 2004). That report differed from the results found in this study, where the animals that received $12 \%$ and $15 \% \mathrm{CP}$ yielded basically the same level of carcass production. This means that in fattened male Bali cattle, an increase in CP concentration up to $15 \%$ is not significantly effective in increasing the carcass production. This difference could be due to genetics, unequal body weights of the cattle being tested, and/or different compilations or sources of feed rations. According to Prado et al. (2014), there was no difference in carcass characteristics between Frisian steers that were fed rations containing low (14.6\%) and high $(16.8 \%)$ levels of protein.

In beef cattle which acquire high concentrate feed during fattening, propionate production in the rumen will be higher as well, which is further converted into glucose to meet the needs of body tissue synthesis process, resulting in a higher carcass production (Fluharty, 2009).

The meat weights $(\mathrm{kg})$ of male Bali cattle fed ration with $12 \% \mathrm{CP}$ and $72 \%$ TDN ( $\mathrm{T}_{1}$ group) and $15 \%$ $\mathrm{CP}$ and $72 \% \mathrm{TDN}\left(\mathrm{T}_{2}\right.$ group) were higher than those in male Bali cattle fed $100 \%$ forage according to the farmer tradition ( $\mathrm{T}_{0}$ group) because both treatments produced higher ADGs (Tahuk et al., 2017) and the slaughter weights. According to Guerrero et al. (2013), the proportion of carcasses and fats in livestock is affected by body weight. The averages daily gains of animals in the male Bali cattle fed rations with $12 \% \mathrm{CP}$ and $72 \%$ TDN ( $\mathrm{T}_{1}$ group) and $15 \% \mathrm{CP}$ and $72 \% \mathrm{TDN}\left(\mathrm{T}_{2}\right.$ group) were 0.70 and $0.47 \mathrm{~kg} / \mathrm{head} /$ day, respectively, contributing to the increased synthesis of body tissue, which led to the higher meat production. Conversely, ADG for the male Bali cattle fed $100 \%$ forage according the farmer tradition ( $\mathrm{T}_{0}$ group) was only $0.30 \mathrm{~kg} / \mathrm{head} /$ day which had a definite impact in lower synthesis of body tissue (Tahuk et al., 2017).

Nevertheless, the meat percentage of the three treatment groups with different crude protein intakes did not vary significantly, with a range of 35.67 to $37.35 \%$. The meat percentage of the male Bali cattle fed $100 \%$ forage according to the farmer tradition ( $\mathrm{T}_{0}$ group) was $37.17 \%$ while in male Bali cattle fed ration with $12 \%$ $\mathrm{CP}$ and $72 \%$ TDN ( $\mathrm{T}_{1}$ group) and $12 \% \mathrm{CP}$ and $72 \% \mathrm{TDN}$ ( $\mathrm{T}_{2}$ group) each amounted to 37.35 and $35.67 \%$ of the slaughter weight. According to Soeparno (2011), beef cattle can produce meat equivalent to approximately $30 \%-40 \%$ of the slaughter weight. Thus, the meat produced in this study was deemed appropriate based on the above range. 


\section{Meat Quality}

Moisture. The results of this research (Table 4) show that male Bali cattle fed 100\% forage had higher moisture content in the meat than those fed with ration with $12 \%$ $\mathrm{CP}$ and $72 \% \mathrm{TDN}$ ( $\mathrm{T}_{1}$ group) and 15\% CP and 72\% TDN ( $\mathrm{T}_{2}$ group). The higher the moisture content of meat in male Bali cattle fed $100 \%$ forage ( $\mathrm{T}_{0}$ group) was closely linked with the low-fat content of meat in this group when compared with male Bali cattle fed ration with $12 \%$ $\mathrm{CP}$ and $72 \%$ TDN ( $\mathrm{T}_{1}$ group) and $15 \% \mathrm{CP}$ and $72 \% \mathrm{TDN}$ ( $\mathrm{T}_{2}$ group). On the other hand, the male Bali cattle fed ration with $12 \% \mathrm{CP}$ and $72 \% \mathrm{TDN}$ ( $\mathrm{T}_{1}$ group) and 15\% $\mathrm{CP}$ and $72 \%$ TDN ( $\mathrm{T}_{2}$ group) had lower moisture contents in the meat because they had higher fat contents in the meats compared with those male Bali cattle fed with $100 \%$ forage ( $\mathrm{T}_{0}$ group). Even though there were differences between the groups of cattle, the meat water levels obtained in this study were still within the normal standard. Theoretically, the water content of the meat has a negative correlation with the fat content of the meat. Differences in water contents in the meat were affected by the intramuscular fat contents. When the fat content of the meat increases, it will decrease the water content of the meat. The water contents of the muscles often had a significant negative correlation with the fat content of the meat (Ueda et al., 2007; Soeparno, 2011).

According to Orellana et al. (2009) and Gebrehiwot et al. (2018), the normal water content in fresh meat ranges from $70 \%-75 \%$. Therefore, the water contents of the meats from the three treatment groups in this study are still in the normal range.

Protein, collagen, and fat. The meat protein contents of the cattle fed ration with $12 \% \mathrm{CP}$ and $72 \%$ TDN ( $\mathrm{T}_{1}$ group) and $15 \% \mathrm{CP}$ and $72 \% \mathrm{TDN}$ ( $\mathrm{T}_{2}$ group) in this study were not significantly different. However, the meat protein contents of the two groups of male Bali cattle fed rations with different $\mathrm{CP}$ percentages were higher than those of male Bali cattle fed $100 \%$ forage ( $T_{0}$ group). The difference in meat proteins between male Bali cattle fed ration with different CP percentages in this study (Table 4) illustrates that the use of protein supplements when balanced with sufficient feed energy may increase the production of meat protein. According to Li et al. (2014), improved feed nutrition such as protein and energy can increase the deposition of fat and protein. These research conditions proved that meat from cattle fed with $100 \%$ forage and meat from cattle fed with diet with higher digestible carbohydrates were not very different in terms of protein contents. For cattle that are in growing phases, the rates of protein synthesis and protein degradation increases, and the rate of protein synthesis is often exceeds the protein degradation. For mature cattle, the rates of synthesis and degradation decrease and eventually reach low and balanced rates of synthesis and degradation (Soeparno, 2011).

The collagen content in the present study was higher in the male Bali cattle fed ration with $12 \% \mathrm{CP}$ and $72 \%$ TDN ( $\mathrm{T}_{1}$ group), followed by those fed ration with $15 \% \mathrm{CP}$ and $72 \%$ TDN ( $\mathrm{T}_{2}$ group) and $100 \%$ forage $\left(\mathrm{T}_{0}\right.$ group). The results of this study indicate the distribu- tion of collagen (\%) in the meat of male Bali cattle vary significantly. The collagen content of meat can differ because it is influenced by the fat content. A relatively high fat content will dissolve or degrade collagen contents (Moon et al., 2006).

The amount of collagen in the meat of male Bali cattle fed ration with $12 \% \mathrm{CP}$ and $72 \% \mathrm{TDN}$ ( $\mathrm{T}_{1}$ group) was not consistent with the above statement because it had fairly high fat content on one side, yet had fairly high collagen levels compared with those fed with 100\% forage ( $\mathrm{T}_{0}$ group) on the other side. This fact may be due to the differences in the amounts of cross-linking in the flesh of each group. The meat from male Bali cattle fed ration with $12 \% \mathrm{CP}$ and $72 \% \mathrm{TDN}$ ( $\mathrm{T}_{1}$ group) was considered to have more cross-linking and collagen fibers. According to Moon (2006), better-quality and highergrade muscles with higher marbling scores and better texture scores tend to have lower total collagen contents.

The fat composition (\%) of the meat in male Bali cattle fed ration with $12 \% \mathrm{CP}$ and $72 \% \mathrm{TDN}$ ( $\mathrm{T}_{1}$ group) was higher than in those fed $100 \%$ forage ( $\mathrm{T}_{0}$ group) (Table 4) indicating that the addition of high-energy ration resulted in the increasing fat content of the meat. Nevertheless, the deposition of fat (inter- or intramuscular) in the meat among cattle fed $100 \%$ forage and those fed with higher digestible carbohydrates did not differ very much, especially in those fed with $15 \% \mathrm{CP}$ and $72 \%$ TDN ( $\mathrm{T}_{2}$ group). According to Gredell et al. (2018), feeding grains in cattle can increase the collagen solubility of the meat produced.

Meat tenderness and cooking loss. Meat tenderness is a major quality characteristic that is highly correlated with the overall consumers' acceptance of beef (CzyżakRunowska et al., 2017). The meat tenderness $\left(\mathrm{kg} / \mathrm{cm}^{2}\right)$ of male Bali cattle fed with $12 \% \mathrm{CP}$ and $72 \% \mathrm{TDN}$ ( $\mathrm{T}_{1}$ group) was higher $(\mathrm{P}<0.05)$ than those of male Bali cattle fed $100 \%$ forage ( $\mathrm{T}_{0}$ group) and $15 \% \mathrm{CP}$ and $72 \% \mathrm{TDN}\left(\mathrm{T}_{2}\right.$ group), which had relatively the same tenderness (Table $4)$. The tenderness of meat in the male Bali cattle fed ration with $12 \% \mathrm{CP}$ and $72 \% \mathrm{TDN}$ ( $\mathrm{T}_{1}$ group) related to the high water-holding capacity and low cooking loss compared with the other two groups. According to Špehar et al. (2008), meat tenderness is influenced by factors such as breed/genetic differences, age, marbling, time of feed, stress - pre-slaughter handling, ageing, and chilling rate; and by the other factors such as intra-muscular connective tissue (IMCT) characteristics represented by total collagen and collagen solubility (Frylinck et al., 2015).

Moreover, the meat tenderness of the male Bali cattle fed ration with $12 \% \mathrm{CP}$ and $72 \%$ TDN ( $\mathrm{T}_{1}$ group) was also related to the high intramuscular fat content. The different levels of fat and collagen content in the muscles affect the meat tenderness value (Lee et al., 2017). The marbling content of the muscles has a positive correlation with the tenderness level. If the marbling content increases, the tenderness of the meat will also increase (Ueda et al., 2007; Highfill et al. 2012; Frylinck et al., 2015). The sources of variations in tenderness in beef may be attributed by carcass composition (marbling), breed/genetics, the age of the animal, the duration of time given feed rations and supplements 
compared to forage, ante-mortem stress (Špehar et al., 2008), and total and soluble collagen (Tullio et al., 2014).

Meat tenderness of both groups of male Bali cattle fed with $100 \%$ forage ( $\mathrm{T}_{0}$ group) and those fed with $15 \%$ $\mathrm{CP}$ and $72 \%$ TDN ( $\mathrm{T}_{2}$ group) did not differ in terms of protein content, water-holding capacity, or meat collagen. These results showed that the use of high-protein and energy feed did not have a significant impact on meat tenderness. According to Scaglia et al. (2012), beef cattle fattening using forage and concentrate produced carcasses with the same tenderness.

The value of tenderness of meat is closely linked with the collagen content of the meat. Nonetheless, this study was inconsistent with the predicted results, because the collagen content of meat in male Bali cattle fed ration with $12 \% \mathrm{CP}$ and $72 \% \mathrm{TDN}$ ( $\mathrm{T}_{1}$ group) was quite high, but on the other hand the tenderness of the meat was higher. Therefore, differences in tenderness of meat in the male Bali cattle in this study were assumed to be caused by the differences in crosslinking of the collagens in the meat.

The meats with collagen crosslinking are heat stable, so heating the meat will increase tension and lower the tenderness of the meat. Conversely, if meats contain collagen which exhibits a heat-labile bond, then heating the meat will result in a greater collagen solubility, so the meat becomes more tender. The main factors that affect the toughness level of meat are the amount of collagen and the collagen solubility level (Lawrie, 2003).

The ranges of results of shear force measurements of the meat tenderness are divided into three categories: namely, tender, with the shear force range of $0-3 \mathrm{~kg} /$ $\mathrm{cm}^{2}$; moderate, with the shear force range of $3-6 \mathrm{~kg} /$ $\mathrm{cm}^{2}$; and tough, with shear force range of $6-11 \mathrm{~kg} / \mathrm{cm}^{2}$. If the shear force measurement results indicate a score of more than 11, then the meat is too tough to be eaten by humans (Pearson \& Dutson, 1985). Referring to the above references, the meat of the male Bali cattle fed ration with $12 \% \mathrm{CP}$ and $72 \% \mathrm{TDN}$ ( $\mathrm{T}_{1}$ group) is quite soft, whereas the meat of male Bali cattle fed 100\% forage ( $\mathrm{T}_{0}$ group) and fed ration with $15 \% \mathrm{CP}$ and $72 \%$ TDN ( $\mathrm{T}_{2}$ groups) are included in the tough category. Meat tenderness in this study was lower than the meat tenderness of Sumba Ongole bulls with averages range of $4.10-5.10 \mathrm{~kg} / \mathrm{cm}^{2}$ (Yantika et al., 2016) and $5.21 \mathrm{~kg} /$ $\mathrm{cm}^{2}$ according to the reports of Kim et al. (2007), and the reports of Khasrad et al. (2017) in Bali cattle that reached $5.84 \mathrm{~kg} / \mathrm{cm}^{2}$.

The meat cooking losses in this study varied, and the male Bali cattle fed $100 \%$ forage ( $\mathrm{T}_{0}$ group) had cooking losses higher than either male Bali cattle fed ration with $12 \% \mathrm{CP}$ and $72 \% \mathrm{TDN}$ ( $\mathrm{T}_{1}$ group) or those fed ration with $15 \% \mathrm{CP}$ and $72 \% \mathrm{TDN}$ ( $\mathrm{T}_{2}$ group). The high cooking loss of meat in male Bali cattle fed with $100 \%$ forage ( $T_{0}$ group) indicates that the meat does not sufficiently protect nutrients during cooking. This result means that in the meat of male Bali cattle fed $100 \%$ forage ( $\mathrm{T}_{0}$ group), the proteins' ability to bind water is weak. As a result, many nutrients were lost along with the drippings that came out of the meat. Conversely, relatively low cooking losses in the meats of male Bali cattle fed ration with $12 \% \mathrm{CP}$ and $72 \%$ TDN ( $\mathrm{T}_{1}$ group) and $15 \% \mathrm{CP}$ and $72 \% \mathrm{TDN}\left(\mathrm{T}_{2}\right.$ group) illustrate that the nutrients in the meat were well preserved (protected) during the cooking process.

The low cooking loss in this study was related to the water holding capacity of the meat, which was quite high (in the range of $14.93 \%-15.79 \%$ ), and an ultimate optimal $\mathrm{pH}$ value that ranged from 5.65-5.74. In addition, the fat contents of the meats in the male Bali cattle fed ration with $12 \% \mathrm{CP}$ and $72 \% \mathrm{TDN}\left(\mathrm{T}_{1}\right.$ group) and $15 \% \mathrm{CP}$ and $72 \%$ TDN ( $\mathrm{T}_{2}$ group) were important in reducing meat cooking loss. Therefore, feeding male Bali cattle during fattening with protein levels of $12 \%$ and $15 \%$ at $72 \%$ TDN had a positive impact on meat cooking losses. Fodder with high enough energy content can increase the synthesis of intramuscular fat (marbling) so as to protect the liquids during the cooking process.

According to Ueda et al. (2007), the cooking loss is negatively correlated with fat content. The increase in the intramuscular fat content can reduce the cooking loss; on the contrary, the low intramuscular fat content can increase the cooking loss. The amount of cooking loss is influenced by the extensive damage to cell membranes, the amount of water that comes out of the meat, the shelf life of the meat, the amount of meat protein degradation, and the ability of the meat to bind water (Shanks, 2002). However, the use of different protein levels does not affect cooking losses (Prado et al., 2015).

Water holding capacity and the degree of acidity. The water-holding capacity (\%) of the meat did not differ significantly between the three groups of male Bali cattle $\left(\mathrm{T}_{0^{\prime}}\right.$ $\mathrm{T}_{1}$, and $\mathrm{T}_{2}$ groups), and the values were within the normal range (Table 4). This result demonstrates that, in general, neither $100 \%$ forage, nor feed containing either $12 \% \mathrm{CP}$ and $72 \%$ TDN or $15 \% \mathrm{CP}$ and $72 \%$ TDN, negatively affected the water-holding capacity of the meat obtained from the male Bali cattle. Normally, water holding capacity is affected by the $\mathrm{pH}$ value of the meat being tested, but the $\mathrm{pH}$ of meats from each of the three treatment groups are all within the normal $\mathrm{pH}$ range of 5.5. Water holding capacity and meat quality levels are closely related to the final $\mathrm{pH}$ of the muscle. The results of this study are not much different from those reported by Agustina et al. (2017) which indicate that the water holding capacities of meats obtained from male and female Bali cattle are relatively similar. According to Lawrie (2003), changes in carcass $\mathrm{pH}$ (post-mortem) affect the water holding capacity; the higher the final $\mathrm{pH}$, the higher the decrease in water-holding capacity of the meat.

According to Cheng \& Sun (2008), factors affecting the water holding capacity (also known as WHC) of red meat products include the growth and development of the meat animals, genotype, diet, stresses, and stunning methods. Other factors that will affect WHC are cooking and cooling procedures for the final meat products: in particular, cooking and cooling methods; the rates of heating and cooling; the cooking temperature; and the endpoint temperature.

The degree of acidity $(\mathrm{pH})$ of the meat from the male Bali cattle in this study was normal and the measurements were relatively equivalent for the meat of male Bali cattle fed ration with different protein and 
total digestible nutrient in the $\mathrm{T}_{0}, \mathrm{~T}_{1}$, and $\mathrm{T}_{2}$ treatment groups. This result demonstrated that the feed treatment given had no significant influence on the meat $\mathrm{pH}$ of the cattle even though high and low $\mathrm{pH}$ were influenced by the total amount of glycogen reserves in the muscle, where muscle glycogen reserves were retained by the three groups of cattle, they were considered not to make much impacts on the meat $\mathrm{pH}$. According to Prado et al. (2014), if the livestock is not stressed before being slaughtered, it will produce meat with a normal $\mathrm{pH}$. The differences between the meat $\mathrm{pH}$ measurements among the cattle in this study were due to the variations between livestock and treatment prior to the cattle being slaughtered.

\section{CONCLUSION}

Male Bali cattle fed rations with crude protein level of $12 \%$ and TDN of $72 \%$ produced a higher-quality carcass, as well as demonstrating that meat quality is higher compared with the control group reared with traditional practices typically used by farmers in fattening cattle. Feeding the male Bali cattle with rations that contain $15 \% \mathrm{CP}$ and $72 \% \mathrm{TDN}$ is not any more effective, because the carcass and meat quality produced is not better than that obtained from the cattle which were fed $12 \%$ crude protein and $72 \%$ TDN.

\section{CONFLICT OF INTEREST}

We declare that there is no conflict of interest related to finance and materials discussed in this publication.

\section{ACKNOWLEDGEMENT}

The authors gratefully express their appreciation to the Minister of Research, Technology, and Higher Education for Doctoral Program Scholarship (BPP-DN) in 2013, and Grants Doctors Dissertation Research through the Directorate of Research and Community Service Implementation Year 2016. Also to the Chairman and members of 'Nekmese' Farmers Group, West Insana District, North Central Timor, East Nusa Tenggara, which were very helpful in setting up the male Bali cattle in order to accelerate the implementation of this research.

\section{REFERENCES}

Abraham R.J.J. \& K. Sivakumar. 2000. Practical manual for Meat Technology and Quality Control. Available at: http://krishikosh.egranth.ac.in/bitstream/1/2040511/1/ TNV-363.pdf.

AMSA (American Meat Science Association). 2015. Research guidelines for cookery, sensory evaluation and instrumental tenderness measurements of meat. Second Edition Version 1.0. American Meat Science Association $201 \mathrm{~W}$ Springfield Ave, Suite 1202 Champaign, Illinois USA 61820.

Agustina, K.K., I.M.R. Dwi Cahya, G.M. Widyantara, I.B.N. Swacita, A.A.G.O. Dharmayudha, \& M.D. Rudyanto. 2017. Nilai gizi dan kualitas fisik daging sapi bali berdasarkan jenis kelamin dan umur (Nutrition level and physical quality of Bali beef according to the sex and age of cattle). Buletin Veteriner Udayana. 9: 156-163.

Ali, H.M., G. Alam, J. A Syamsu, Salengke, \& M. A Asja. 2014. Average daily gain, AST and blood nitrogen urea (BUN) responses of bali beef on cocoa waste extract supplement. Journal of Advanced Agricultural Technologies. 1: 5 - 9 . https://doi.org/10.12720/joaat.1.1.5-9

Cheng, Q. \& D.W Sun. 2008. Factors affecting the water holding capacity of red meat products: a review of recent research advances. Crit. Rev. Food Sci. Nutr. 48:137-159. https:// doi.org/10.1080/10408390601177647

Czyżak-Runowska, G., B. Grześ, E. Pospiech, J. Komisarek, M. Okulicz, D. Stanisławski, \& M. Markiewicz-Kęszycka. 2017. Meat quality of Limousin young bulls slaughtered at 6, 9 and 12 months of age. Emirates Journal of Food and Agriculture. 29:792-798. https://doi.org/10.9755/ejfa.2017. v29.i10.1297

Fluharty, F. L. 2009. Interactions of management and diet on final meat characteristics of beef animals. Beef Information, The Ohio State University Extension. http://beef.osu.edu/ library/mgtdiet.html. Akses 9 Desember 2015.

Frylinck, L., A. O'Neil, E. du Toit, P.E. Strydom, \& E.C. We. 2015. The beef tenderness model. S. Afr. J. Anim. Sci. 45: 234-248.

Gebrehiwot, M., E. Balcha, Y. H Hagos, \& K. W/rkelul. 2018. Determination of $\mathrm{pH}$ and water holding capacity of beef from selected butcher shops of Mekelle, Ethiopia. J. Vet. Med. Anim. Health. 10: 159-164.

Gleghorn, J. F., N. A. Elam, M. L. Galyeant., G. C. Duff, N. A. Cole., \& J. D. Riverat. 2004. Effects of crude protein concentration and degradability on performance, carcass characteristics, and serum urea nitrogen concentrations in finishing beef steers. J. Anim. Sci. 2004. 82:2705-2717. https://doi.org/10.2527/2004.8292705x

Gredell, D.A., T.G. O'Quinn, J. F. Legako, J. C. Brooks, \& M.F. Miller. 2018. Palatability and Biochemical Factors of Beef from Mature Cattle Finished on a Concentrate Diet Prior to Harvest. Meat and Muscle Biology. 2:111-126. https://doi. org/10.22175/mmb2017.09.0046

Guerrero, A., M. V. Valero, M. M Campo, \& C. Sañudo. 2013. Some factors that affect ruminant meat quality: from the farm to the fork. Review. Maringá. 35: 333-347.

Hartadi, H., S. Reksohadiprodjo, S. Lebdosukojo, A.D. Tillman, L.C. Kearl, \& L.E. Harris. 1980. Tables of feed composition for Indonesia. IFI., Utah Agricultural Experiment Station, Utah State University, Logan, UT., USA., pp:12.

Highfill, C.M., O. Esquivel-Font, M.E. Dikeman, \& D.H. Kropf. 2012. Tenderness profiles of ten muscles from F1 Bos indicus $\mathrm{x}$ Bos taurus and Bos taurus cattle cooked as steaks and roasts. Meat Sci. 90: 881-886. https://doi.org/10.1016/j. meatsci.2011.11.022

Jama, N., V. Muchenje, M. Chimonyo, P. E. Strydom, K. Dzama, \& J. G. Raats. 2008. Cooking loss components of beef from Nguni, Bonsmara and Angus steers. African Journal of Agricultural Research. 3: 416-420.

Khasrad, Sarbaini, Arfa'I, \& Rusdimansyah. 2017. Effect of cattle breeds on the meat quality of Longissimus dorsi muscles. Pak. J. Nutr. 16: 164-167. https://doi.org/10.3923/ pjn.2017.164.167

Kim, Y.S., A. Ong, N. Bobbili, M.W. DuPonte, \& G.K. Fukumoto. 2007. Evaluation of meat tenderness of foragefinished cattle produced in Hawai' $\mathrm{i}$, and factors affecting the tenderness. Food Safety and Technology (FST)-27: 1-7.

Lawrie, R.A. 2003. Ilmu Daging. Penerjemah: Aminuddin Parakkasi. Penerbit Universitas Indonesia Press, Jakarta.

Lee, K.-W., Y.-H. Hwang, \& S.-T. Joo. 2017. Meat tenderness characteristics of ten major muscles from Hanwoo steers according to quality grades of carcasses. Korean Journal 
for Food Science of Animal Resources 37:593-598. https:// doi.org/10.5851/kosfa.2017.37.4.593

Li, L., Y. Zhu, X. Wang, Y. He, \& B. Cao. 2014. Effects of different dietary energy and protein levels and sex on growth performance, carcass characteristics and meat quality of F1 Angus $\times$ Chinese Xiangxi yellow cattle. Journal of Animal Science and Biotechnology. 5: 1-12. https://doi. org/10.1186/2049-1891-5-21

Moon, S.S. 2006. The effect of quality grade and muscle on collagen contents and tenderness of intramuscular connective tissue and myofibrillar protein for Hanwoo beef. AsianAust. J. Anim. Sci. 19: 1059-1064.

Oka, I.G.L., I.P. Suyadnya., S. Putra., I.M. Suarna., N. Suparta., I.K. Saka., N.K. Suwiti., I.M. Antara., I.N. Puja., I.W. Sukanata., A.A. Oka., \& I.M. Mudita. 2012. Sapi Bali Sumber Daya Genetik Asli Indonesia. Udayana University Press. Pp. 268-277.

Orellana, C., F. Peña, A. García, J. Perea, J. Martos, V. Domenech, \& R. Acero. 2009. Carcass characteristics, fatty acid composition, and meat quality of Criollo Argentino and Braford steers raised on forage in a semi-tropical region of Argentina. Meat Sci. 81: 57-64. https://doi. org/10.1016/j.meatsci.2008.06.015

Osborne, B.G. 2006. Application of near infrared spectroscopy in quality screening of early-generation material in cereal breeding programmes. Journal of Near Infrared Spectroscopy. 14: 93-101. https://doi.org/10.1255/jnirs.595

Panjaitan, T., M. Fauzan, Dahlanuddin, M. Halliday, \& H. M. Shelton. 2014. Growth of Bali bulls fattened with Leucaena leucocephala in Sumbawa, Eastern Indonesia. Tropical Grasslands - Forrajes Tropicales. 2:116-118.

Pearson, A.M. \& T.R. Dutson. 1985. Advance in Meat Research. Vol. 1. Electrical Stimulation. Avi Publishing Company, Inc. Westport, Connecticut. https://doi. org/10.1007/978-94-011-5939-5

Prado, I. N., M. M. Campo, E. Muela, M. V. Valero, O. Catalan, J. L. Olleta, \& C. Sañudo. 2014. Effects of castration age, dietary protein level and lysine/methionine ratio on animal performance, carcass and meat quality of Friesian steers intensively reared. Animal 8: 1561-1568. https://doi. org/10.1017/S1751731114001591

Scaglia, G., PAS, J. P. Fontenot, PAS, W. S. Swecker Jr., B. A. Corl., S. K. Duckett, PAS, H. T. Boland, R. Smith, \& A. O. Abaye. 2012. Performance, carcass, and meat characteristics of beef steers finished on 2 different forages or on a high-concentrate diet. The Professional Animal Scientist. 28:194-203. https://doi.org/10.15232/ S1080-7446(15)30340-5
Shanks, B. C., D.M. Wolf, \& R. J. Maddock. 2002. Technical note: The effect of freezing on warner bratzler shear force values of beef longissimuss steak across several postmortem aging periods. J. Anim. Sci 80: 2122-2125.

Soeparno. 2011. Ilmu Nutrisi dan Gizi Daging. Edisi Pertama. Gadjah University Press. Yogyakarta.

Špehar, M., D. Vincek, \& S. Žgur. 2008. Beef Quality: Factors Affecting Tenderness and Marbling. Review paper. Stočarstvo. 62: 463-478.

Steel, R.G.D \& J.H. Torrie. 1995. Prinsip Dan Prosedur Statistika. Penterjemah Bambang Sumantri. Gramedia Pustaka, Jakarta.

Suryanto, E., Bulkaini, Ashari, \& I.W. Karda. 2014. Carcass quality, marbling and cholesterol content of male bali cattle fed fermented cocoa shell. J. Indonesian Trop. Anim. Agric. 39:249-255. https://doi.org/10.14710/jitaa.39.4.249-255

Tahuk, P. K. \& A.A. Dethan. 2010. Performance of Bali bull in greenlot fattening by farmers when rainy season in Timor island. J. Indonesian Trop. Anim. Agric. 35:257-261. https:// doi.org/10.14710/jitaa.35.4.257-261

Tahuk, P.K., S.P.S Budhi, Panjono, N. Ngadiyono, R. Utomo, C. T. Noviandi, \& E. Baliarti. 2017. Growth performance of male Bali cattle fattening fed ration with different protein levels in smallholder farms, West Timor, Indonesia. Asian Journal of Animal Sciences. 11: 65-73. https://doi. org/10.3923/ajas.2017.65.73

Tahuk, P.K., S. P. S. Budhi, Panjono, \& E. Baliarti. $2018^{\text {a }}$ Nitrogen balance, microbial protein synthesis and blood metabolites in fattening of male Bali cattle fed ration with different protein levels in smallholder farms. J. Indonesian Trop. Anim. Agric. 43:43-53. https://doi.org/10.14710/ jitaa.43.1.43-53

Tahuk, P.K., E.Baliarti, S. P. S. Budhi, \& Panjono. 2018 ${ }^{\text {b }}$ The effect of season on the feed quantity and quality and growth performance of male Bali cattle fattened in smallholder farms. Buletin Peternakan 42: 203-209.

Tullio R.R., M. Jua, I.L. Larsen, J.A. Basarab, \& J.L. Aalhus. 2014. Influence of some meat quality parameters on beef tenderness. Can. J. Anim. Sci. 94: 455-458. https://doi. org/10.4141/cjas2013-157

Ueda, Y., 1 A. Watanabe, M. Higuchi, H. Shingu, S. Kushibiki, \& M. Shinoda. 2007. Effects of intramuscular fat deposition on the beef traits of Japanese Black steers (Wagyu). Animal Science Journal. 78: 189-194. https://doi. org/10.1111/j.1740-0929.2007.00424.x

Yantika, S.M., Alamsyari, D. Evvyernie, D. Diapari, \& K. Winaga. 2016. Performance, carcass production, and meat quality of Sumba Ongole bulls fed ration supplemented velvet bean (Mucuna pruriens). Med. Pet. 39:20-26. https:// doi.org/10.5398/medpet.2016.39.1.20 